\title{
Corneşti-Iarcuri - a Bronze Age town in the Romanian Banat?
}

\author{
Alexandru Szentmiklosi ${ }^{1}$, Bernhard S. Heeb ${ }^{2}$, Julia Heeb ${ }^{3}$, \\ Anthony Harding ${ }^{3}$, Rüdiger Krause ${ }^{4} \&$ Helmut Becker $^{5}$
}

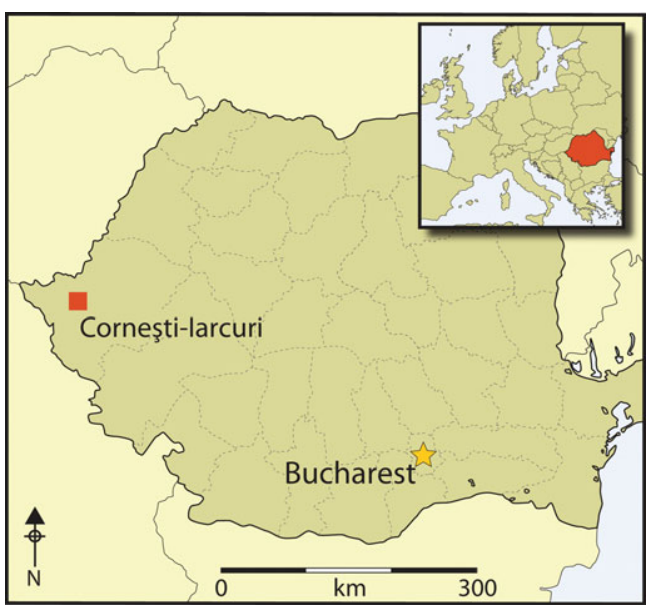

A massive Late Bronze Age fortified settlement in Central Europe has been the subject of a new and exemplary investigation by excavation and site survey. This prehistoric enclosure, nearly $6 \mathrm{~km}$ across, had a complex development, dense occupation and signs of destruction by fire. It can hardly be other than a capital city playing a role in the determinant struggles of its day - weighty and far reaching events of the European continent now being chronicled by archaeology.

Keywords: Romania, Bronze Age, fortified sites, magnetic prospection, caesium magnetometry, evaluation, site survey

\section{Introduction}

In the expansive plains of the Banat in western Romania, between the cities of Arad and Timişoara, lies the multiple enclosure of Iarcuri, in the immediate vicinity of the modern village of Corneşti (Figure 1). The site, which encompasses four enclosing rings of ramparts, and has an area of about $1722 \mathrm{ha}$, is at present the largest known prehistoric settlement in Europe. The dimensions can only really be grasped when looking at the site from the air (Figure 2).

Already in the nineteenth century, Corneşti-Iarcuri (then known by the Hungarian name Zsadány, Romanian Jadani, German Schadain, as shown on Austrian military maps) was

1 Muzeul Banatului Timişoara, Piaţa Huniade, nr. 1, Castelul Huniazilor, 300002 Timişoara, Romania

2 Museum für Vor-und Frühgeschichte der Staatlichen Museen zu Berlin, Schloss Charlottenburg, Langhansbau, 14059 Berlin, Germany

3 Department of Archaeology, University of Exeter, Laver Building, North Park Road, Exeter EX4 4QE, UK

4 Institut für Archäologische Wissenschaften, Johann Wolfgang von Goethe-Universität Frankfurt am Main, Grüneburgplatz 1, G0323 Frankfurt am Main, Germany

5 Becker Archaeological Prospection, Loisachweg 32, 82547 Beuerberg, Germany 


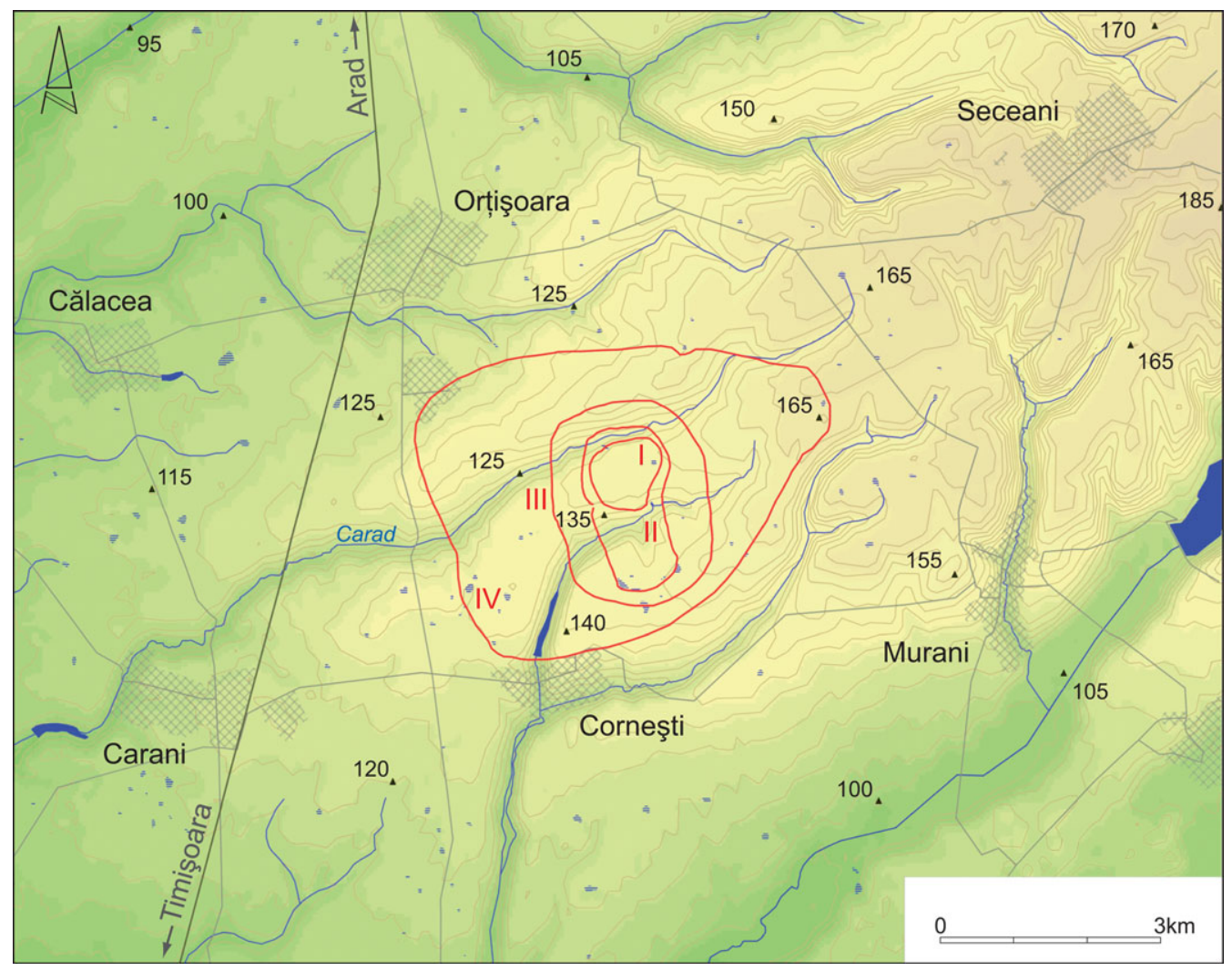

Figure 1. Corneşti-Iarcuri: outline of the defensive works mapped onto the local topography.

part of the archaeological discourse, mainly due to its immense size (Pech 1877; Milleker 1899). When Austrian settlers mapped the marshy expanses of the Banat, parts of the two inner enclosures appeared on a 'Mercy Map' (map series created between 1723 and 1725 by Count Claude Florimund de Mercy, commander of the Banat 1716-1730) (Heeb et al. 2008: 182, Abb. 4). More detailed maps of the site, including the third enclosure, were created by the military in the nineteenth and early twentieth centuries. The outermost enclosure was only discovered in 1973 on aerial photographs, as it is hardly visible on the ground. It was published for the first time in 1989 (Rada et al. 1989). A recent description of the site was provided by D. Micle and colleagues from the West University of Timişoara (Micle et al. 2006), who also undertook initial survey work and considered the site's situation in its local context.

The innermost, almost circular, rampart (hereafter Enclosure I) has a diameter of $1 \mathrm{~km}$ (east-west) and is flanked to the north and south by two valleys (Figure 3). The second enclosure (Enclosure II) is more oval in nature and has a diameter (north-south) of about $2.2 \mathrm{~km}$, encompassing Enclosure I, the two valleys, as well the southern terraces and plateau. The third rampart (Enclosure III) is also oval in shape with a diameter (north-south) of $2.8 \mathrm{~km}$. The total area of over $1700 \mathrm{ha}$ is that of the outermost ring (Enclosure IV), which 


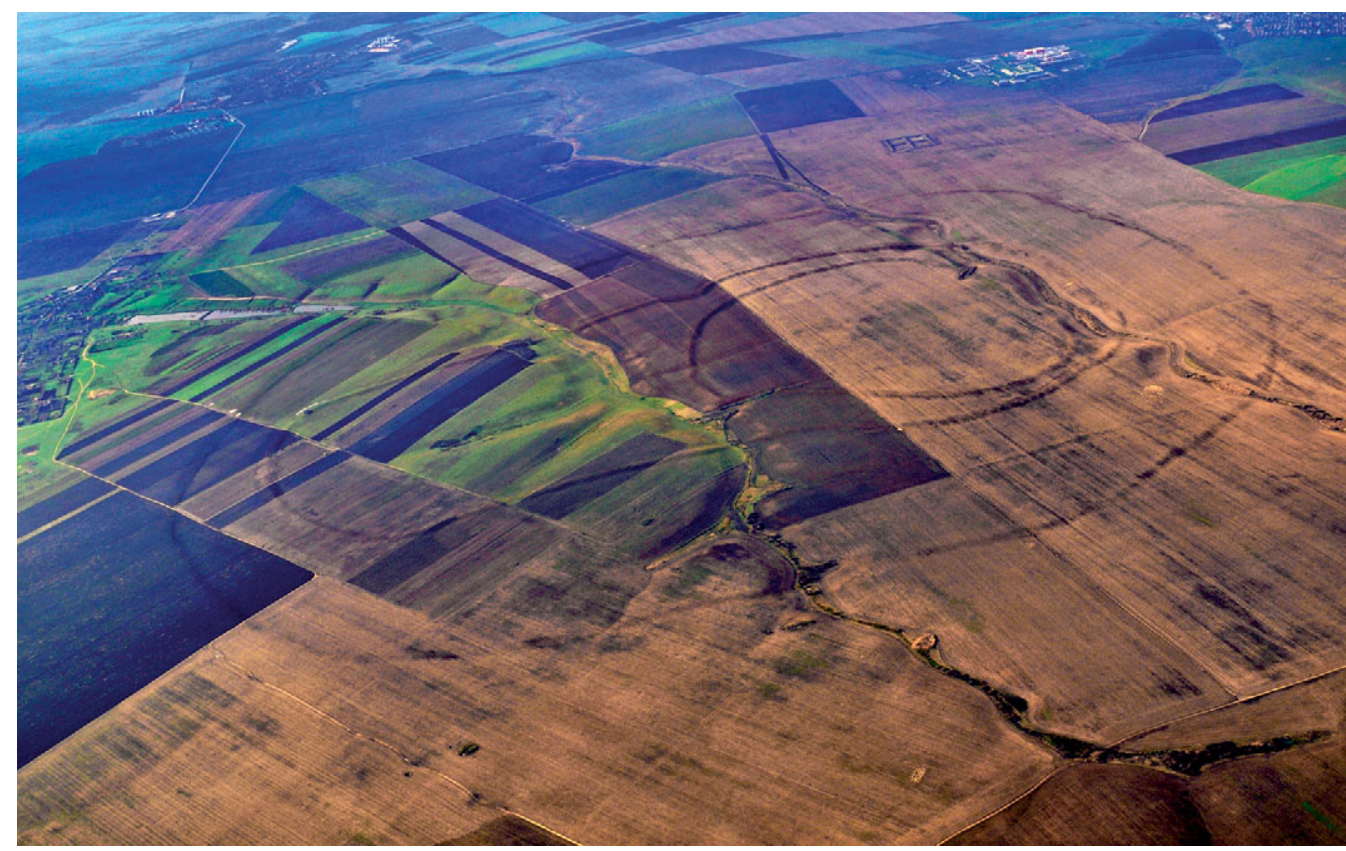

Figure 2. Aerial view of Corneşti-Iarcuri from the east (photograph: D. Baltat).

measures $5.5 \mathrm{~km}$ east-west and c. $3.9 \mathrm{~km}$ north-south, with a perimeter length of almost 16km (Micle et al. 2006: 286-90; Heeb et al. 2008: 185).

I. Miloia and M. Moga carried out the first excavations on the site in 1932 and 1939 respectively (Medeleţ 1993). The records for the excavations of the 1930s survive only in fragmentary form. Trenches opened in 1939 (A and B) cut across the rampart of Enclosure II. The available section drawing shows parallel rows of vertical wooden posts filled with soil (Heeb et al. 2008: 183). They were probably joined up with wattle, and the structure shows signs of burning. Plans for further excavations were thwarted by the outbreak of World War II.

In autumn 2007 excavation and survey work was resumed by a team from Romania, Germany and Britain, when a small test trench was excavated in the southern half of Enclosure II (Trench 1). In 2008 Enclosure I was investigated in order to understand the method of construction and possible date by excavating a long narrow trench through the rampart (Trench 2), using students and staff from the universities of Timişoara, Cluj-Napoca, Arad, Frankfurt am Main, Berlin, Würzburg and Exeter, and the Timişoara Museum. In parallel with the excavation, high resolution magnetic prospection (by Becker Archaeological Prospection) and a field-walking survey were carried out.

The experience of 2007 and 2008 showed that small-scale excavations are ineffective due to the immense scale of the site, and larger-scale excavations, especially those cutting the ramparts, have major consequences for time and funding. Trying to locate smaller features without prior geophysical survey is like looking for a needle in a haystack. Systematic research is, however, crucial as intensive agriculture is endangering the entire site. In places the ramparts have already been levelled, although in other parts they are still preserved up to a height of $4 \mathrm{~m}$. It was therefore decided to undertake a three-week long prospection 

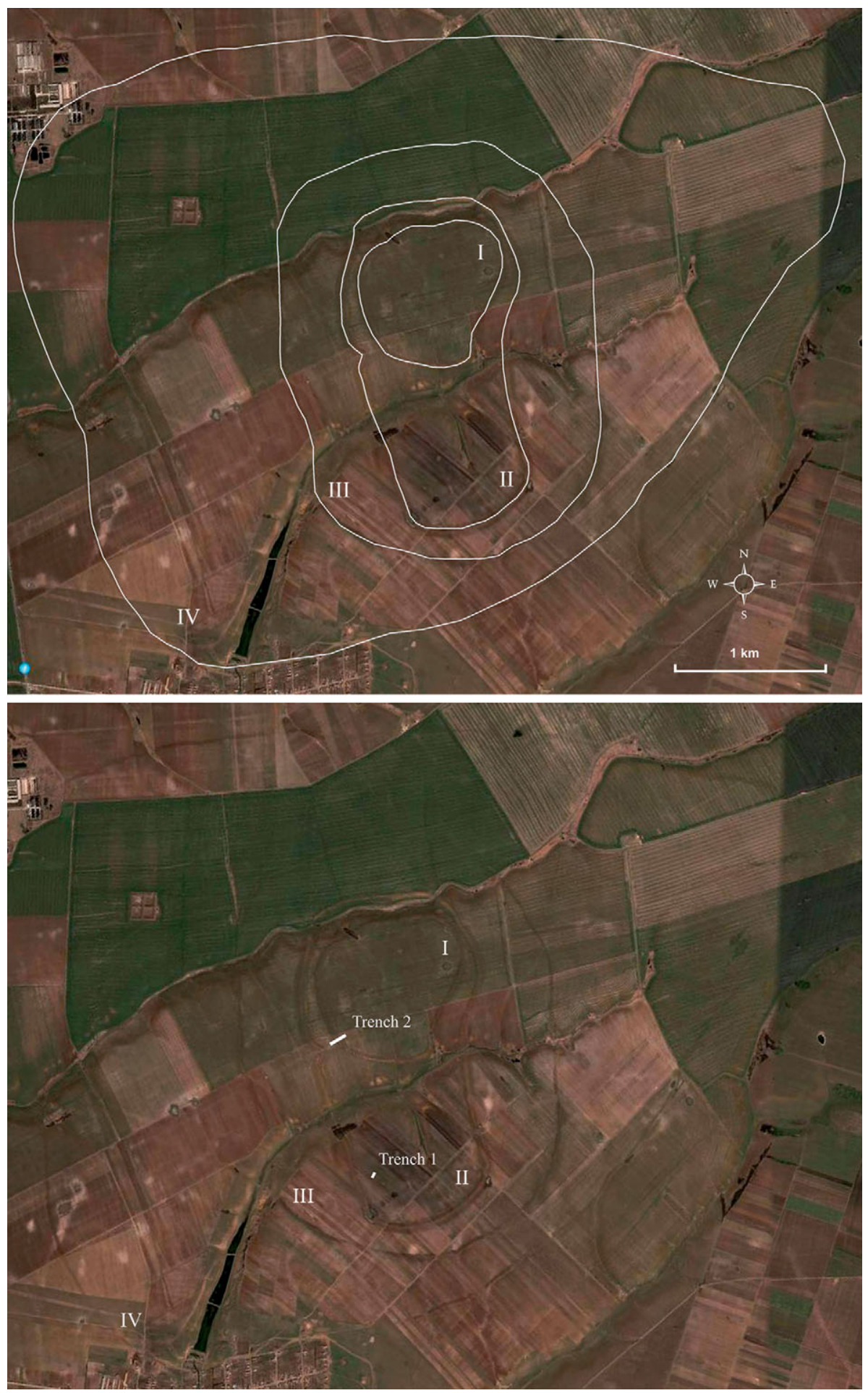

Figure 3. Satellite images of Cornești-Iarcuri (height: 9.8km): upper) the course of the four enclosures superimposed on the satellite image; lower) location of Trenches 1 and 2 (Google Earth, modified). 


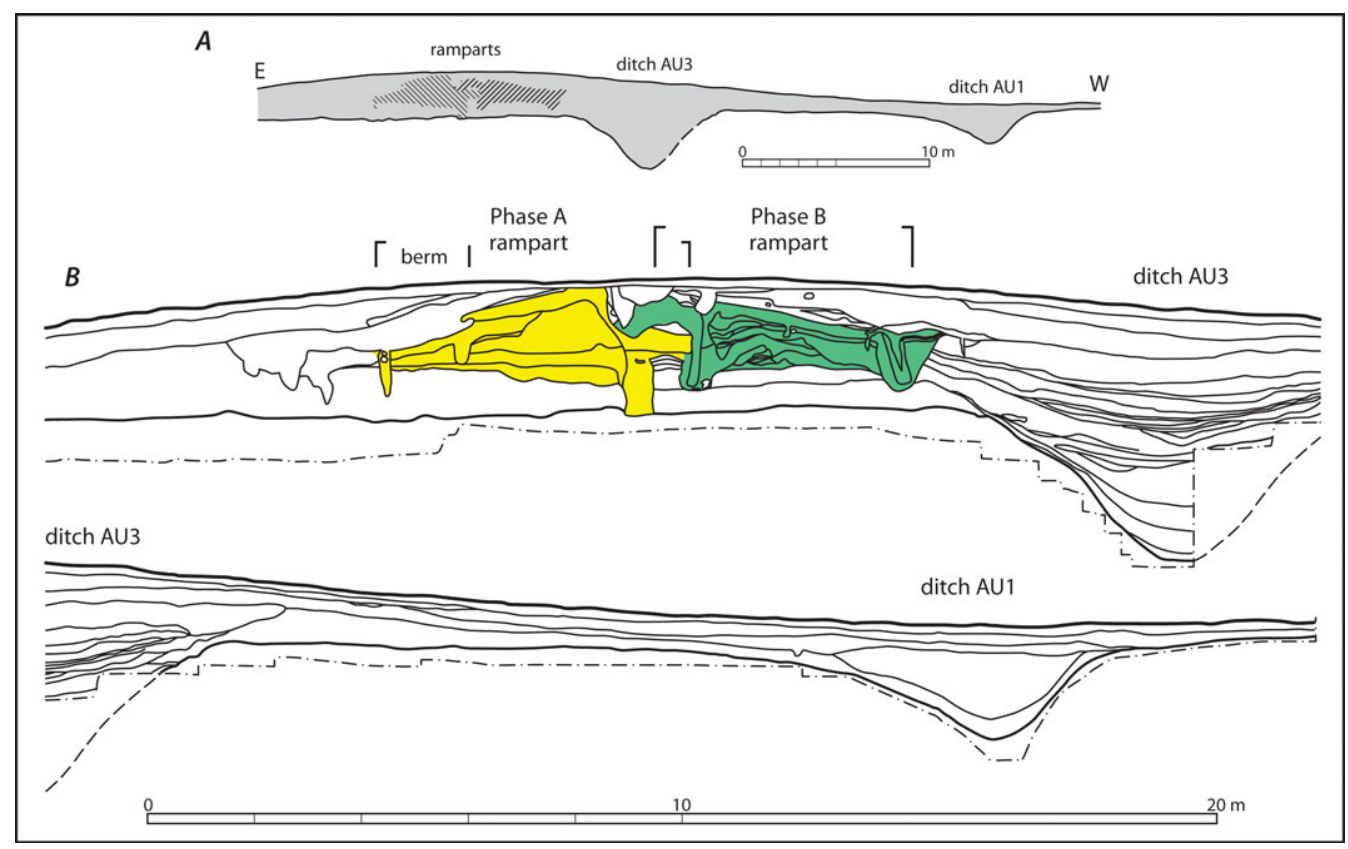

Figure 4. Trench 2, south profile: A) complete profile shown schematically; B) eastern and western halves of the south profile.

campaign in 2009, carrying out magnetic and topographic surveys, systematic field-walking, as well as archaeobotanical coring by Dr J. Kalis, Department of Archaeobotany, Institut für Vor- und Frühgeschichte, Universität Frankfurt am Main (who describes the samples as 'suboptimal'). These activities all took place within the southern half of Enclosure II.

\section{Excavations 2007-2008}

\section{Trenches 1 and 2 (Figure 3, lower)}

The trench opened in October 2007 (Trench 1) was intended to determine whether the intensively farmed interior of Enclosure II still contained archaeological layers. Although too small $(2 \times 10 \mathrm{~m})$ to uncover the larger picture, it was possible to identify at least two cultural layers, as well as a number of pits and postholes beneath the ploughsoil (Heeb et al. 2008: 185-6). The stratified layers were about $1 \mathrm{~m}$ thick. Apart from a bronze earring and a small knife fragment, only undecorated sherds were found. It was therefore not possible to date the layers any closer than to the Late Bronze Age/Early Iron Age. Although the excavation indicated the presence of a prehistoric settlement within the second enclosure, it was not possible to establish its temporal relationship to the ramparts.

In 2008 , a trench of $80 \times 3.6 \mathrm{~m}$ was cut with the aim of obtaining a complete profile through the rampart and ditches of Enclosure I (Trench 2, Figure 3). The rampart proved to have been constructed in two phases (I/A and I/B) (Figure 4). Although both phases consisted of earth-filled wooden constructions made from large beams, the finer details demonstrate substantial differences in their overall construction. Three main elements belong to phase I/A: ditch AU3 outside the rampart; the rampart, consisting of earth-filled 

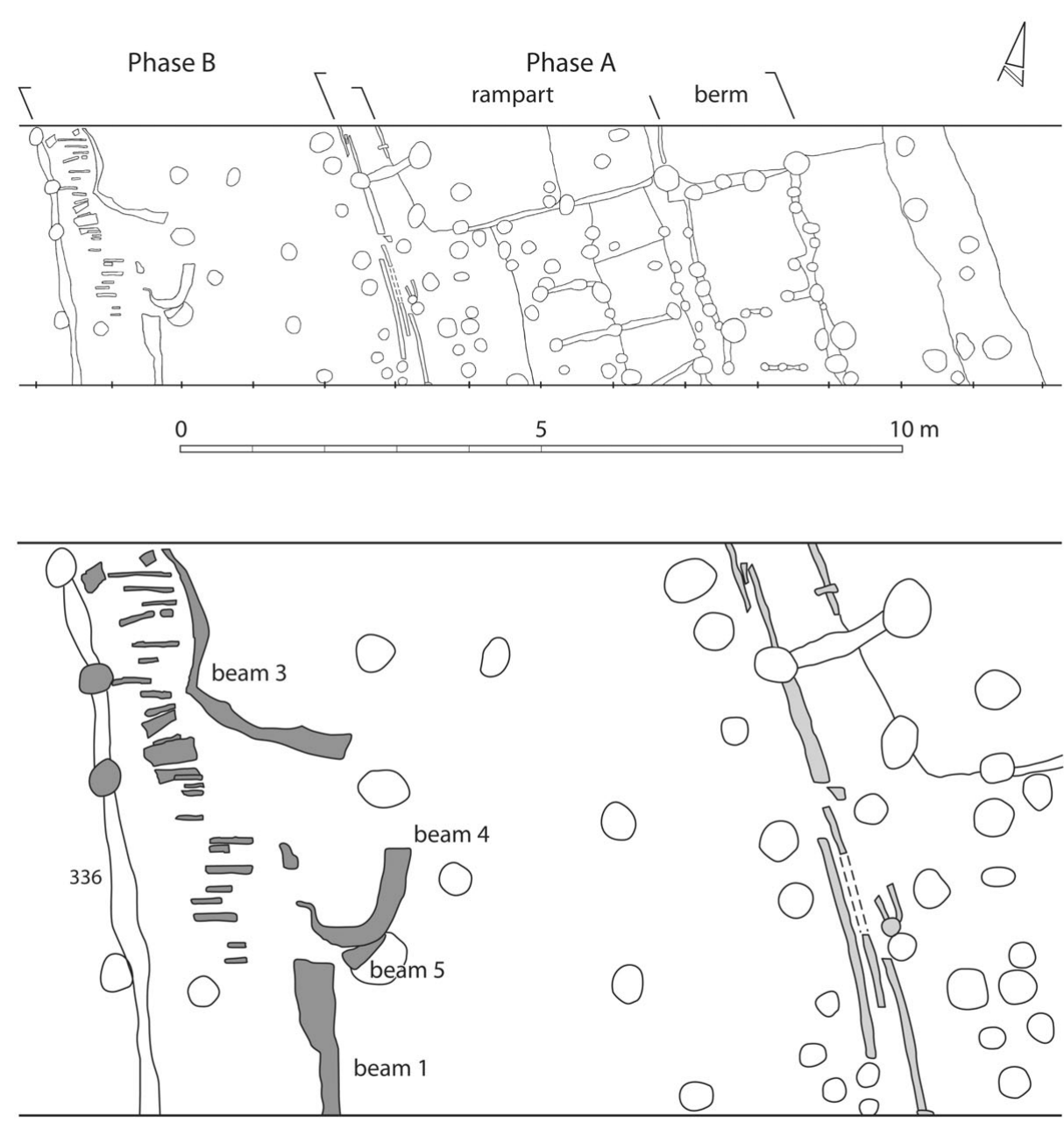

Charcoal (oak) Ash

0 $5 \mathrm{~m}$

Figure 5. Plan of Trench 2, level 2: upper) complete plan; lower) detail of western part.

wooden compartments (yellow on Figure 4); and a berm adjoining the inner face of the rampart. Ditch AU3 lies $4 \mathrm{~m}$ in front of rampart I/A, and is $11 \mathrm{~m}$ wide and $4.7 \mathrm{~m}$ deep. Rampart I/A had been constructed using wooden posts and beams as well as soil. The core structure consists of four parallel rows of posts, forming three longish strips in the interior of the rampart (Figure 5). The fill of the wooden compartments was most probably taken from the huge ditch AU3 outside the rampart and a shallow depression on the inside. The varying soil colours in the compartments might suggest that the earth came from different locations (Figure 6). Although there were no traces of burning (charcoal or ash) visible in 
Alexandru Szentmiklosi et al.

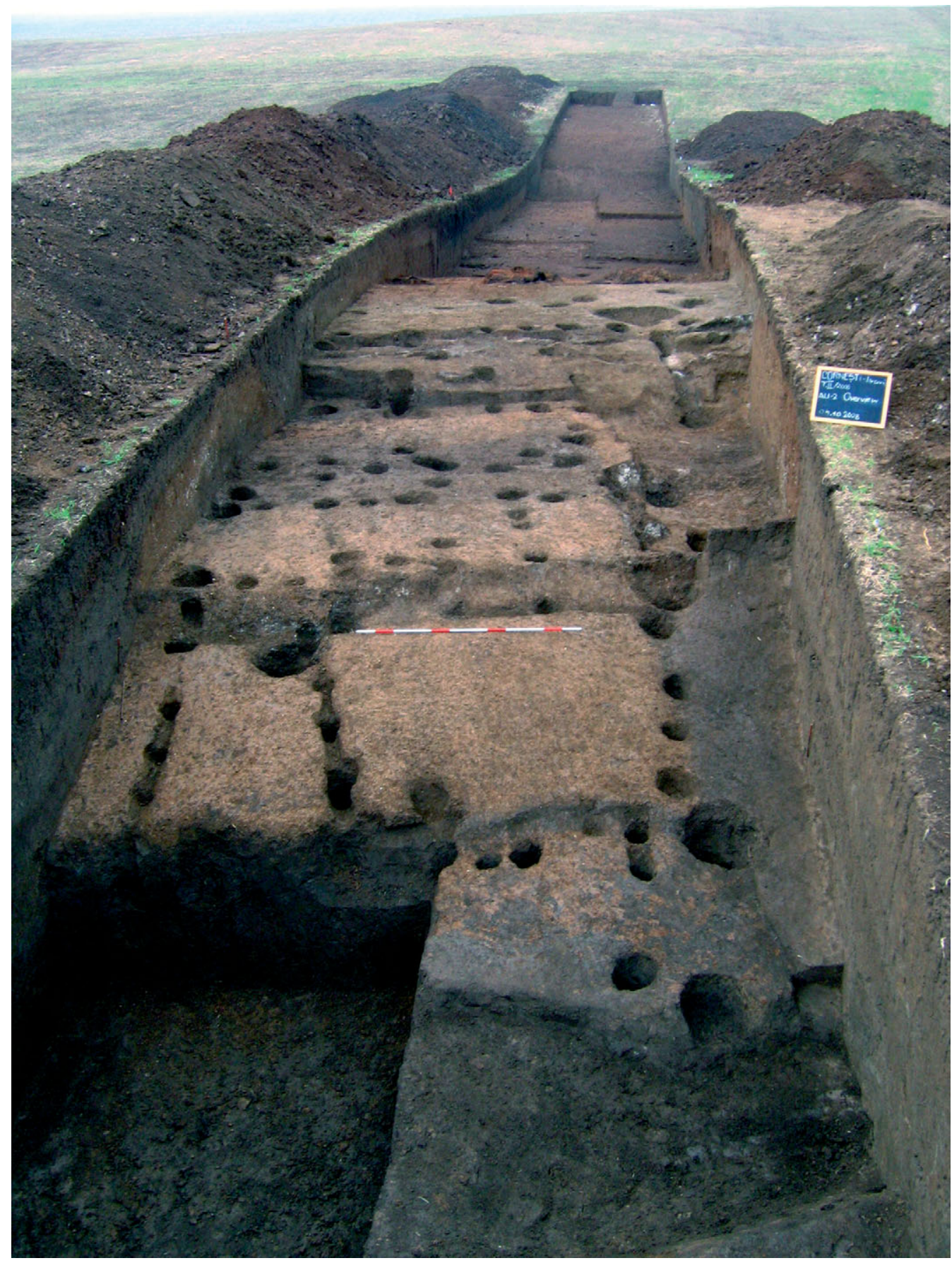

ปี

Figure 6. Overall view of Trench 2 from the east. 


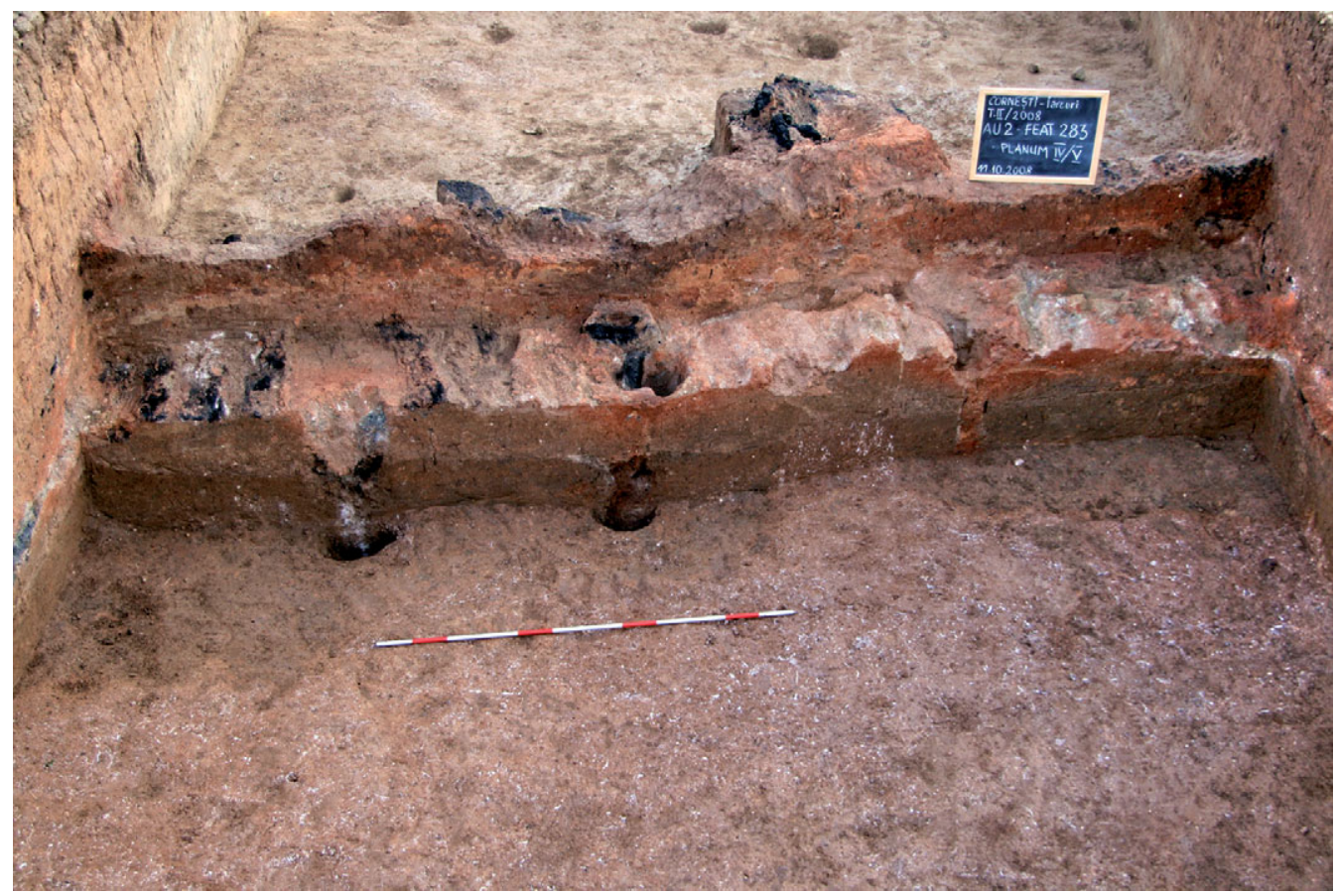

Figure 7. Burnt timbers at the outer edge of phase B, from the west.

phase $A$, the magnetogram indicates that the fire destroying phase B (see below) also had an oxidising effect on the soil of phase A. A possible berm had been built on the inside edge of rampart I/A, which was $1.2 \mathrm{~m}$ deep and about $0.8 \mathrm{~m}$ high. The function of this berm remains uncertain, although it might have stabilised the interior edge of the rampart and helped drain rainwater away. In Trench 2 the rampart was preserved to a height of $1.9 \mathrm{~m}$. It can be assumed, however, that the rampart once stood around $5 \mathrm{~m}$ high; the size of the ditch ( $11 \mathrm{~m}$ wide and $5 \mathrm{~m}$ deep) from which the soil was used to build the rampart suggests the same. The width of the construction in phase A was almost exactly $5 \mathrm{~m}$, including both the rampart $(3.8 \mathrm{~m})$ and the berm $(1.2 \mathrm{~m})$.

In phase $\mathrm{B}$, the ditch $\mathrm{AU} 3$ was probably infilled when a new rampart I/B was constructed about $1 \mathrm{~m}$ beyond the outer edge of rampart I/A, and therefore partly overlaid ditch AU3. An outer ditch AU1, which is $7 \mathrm{~m}$ wide and $2.1 \mathrm{~m}$ deep, lies $24 \mathrm{~m}$ outside rampart I/B (Figure 4). The magnetogram showed that ditch AU1 is interrupted in front of rampart I/B at all the gate areas (see Figure 12 below), which means that it probably belonged to the more recent phase $\mathrm{B}$, although this was not directly verifiable in the stratigraphy (see below). There was no obvious occasion (for example traces of burning in phase A) for the construction of the new rampart. When phase $B$ was built, parts of phase A were still standing. The construction method of phase B is visibly different (green on Figure 4). Posts were positioned within a foundation trench along the eastern edge of ditch AU3, at irregular intervals of $0.4 \mathrm{~m}, 0.6 \mathrm{~m}$ and $1 \mathrm{~m}$, leaning inwards at an angle of about $15^{\circ}$ (Figure 7 ). This row of posts along the outer edge of the rampart was held together by horizontal beams, which were preserved in 


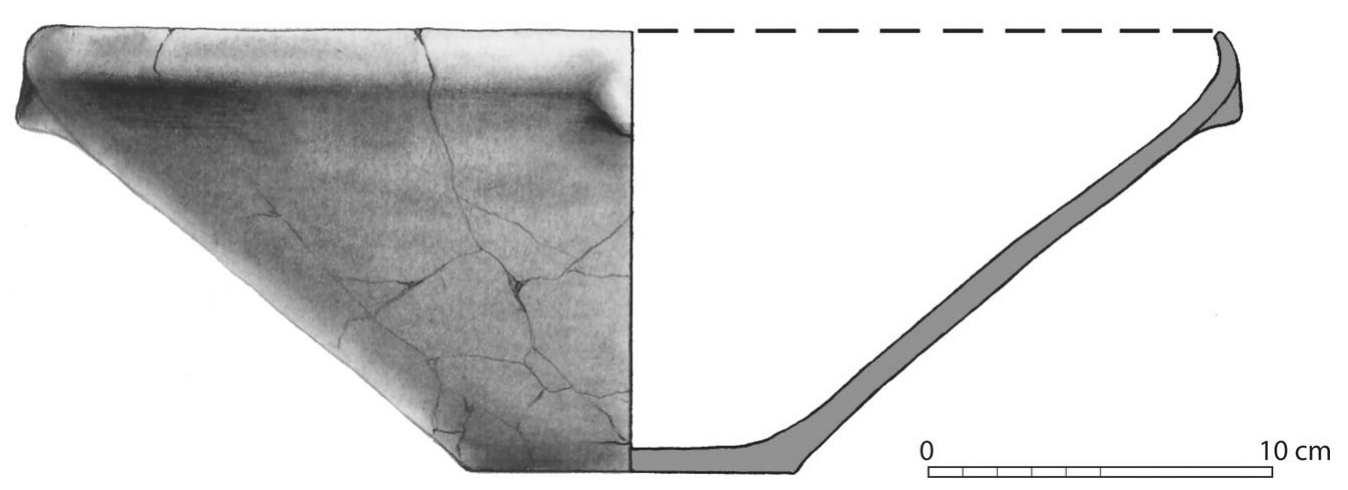

Figure 8. Bowl from the lower levels of phase $B$.

two layers. Between these two layers, shorter horizontal beams running at a $90^{\circ}$ angle to the rampart protruded about $0.5 \mathrm{~m}$ into it. In addition, the magnetogram shows that transverse beams connected the inner and outer edges of the rampart.

Rampart I/B was burnt, causing the structures to be preserved in great detail. Its beams, made from oak (J. Kalis pers. comm.), were subject to intense burning, predominantly on their outer edge. The large amount of burnt daub suggests that the outside of the rampart was partly daubed. The fire that destroyed phase B must have burned at extremely high temperatures, as the imprints of the short beams were clearly visible (Figure 7). After the firing of rampart I/B, no steps were taken to repair or rebuild it, at least in the area excavated.

\section{Dating}

A complete bowl recovered at the exterior foot of the phase $\mathrm{B}$ rampart can be dated to the Cruceni-Belegiş IIA phase (equivalent to Hallstatt A1) (Figure 8). The Cruceni-Belegiş culture is part of the south-east European Urnfield culture, with a distribution similar to the preceding Vatina group in Oltenia, Banat and eastern Hungary. In terms of relative chronology, it is situated between the Middle Bronze Age Vatina culture and the Early Iron Age Gornea-Kalakača culture. The absolute chronology places the group between the fifteenth and eleventh centuries BC (Szentmiklosi 2009).

Three samples for radiocarbon dating were taken from burnt beams belonging to the later construction. The results provide a clear indication of construction between 1450 and $1200 \mathrm{cal} \mathrm{BC}$ (Table 1 and Figure 9) combined to give a construction date of 1393-1314 (at $68.2 \%$ probability), and 1411-1270 (at 95.4\%) (Figure 10).

\section{Magnetic prospection 2008-2009}

Magnetic prospection was carried out in $40 \mathrm{~m}$ grids using a metronome to maintain a constant speed when walking. With this rather simple method about 2 ha were measured per day (more than 400000 points with $0.1 \times 0.5 \mathrm{~m}$ resolution). The location and extent of the survey areas are shown on Figure 11. 
Table 1. Radiocarbon dates (all on charred material from the indicated contexts). Calibration at $2 \sigma$ using OxCal v.4.1.7.

\begin{tabular}{lccccc}
\hline Lab no. & $\begin{array}{c}\text { Archaeological } \\
\text { context }\end{array}$ & Pretreatment & ${ }^{13} \mathbf{C} /{ }^{12} \mathbf{C}$ & Age BP & $\begin{array}{c}\text { Calibrated age BC } \\
\text { (\% probability) }\end{array}$ \\
\hline Beta-258640 & Beam 6 & Acid/alkali/acid & $-24.5 \%$ & $3060 \pm 40$ & $1418-1209(95.4 \%)$ \\
Beta-258641 & Beam 7 & Acid/alkali/acid & $-24.4 \%$ & $3110 \pm 40$ & $1601-1592(0.7 \%)$ \\
& & & & & $1532-1392(94.7 \%)$ \\
Beta-258642 & Beam 11 & Acid/alkali/acid & $-23.8 \%$ & $3040 \pm 40$ & $1396-1153(92.0 \%)$ \\
& & & & & $1146-1129(3.4 \%)$ \\
\hline
\end{tabular}

OxCal v4.1.7 Bronk Ramsey (2010); r:5 Atmospheric data from Reimer et al (2009);

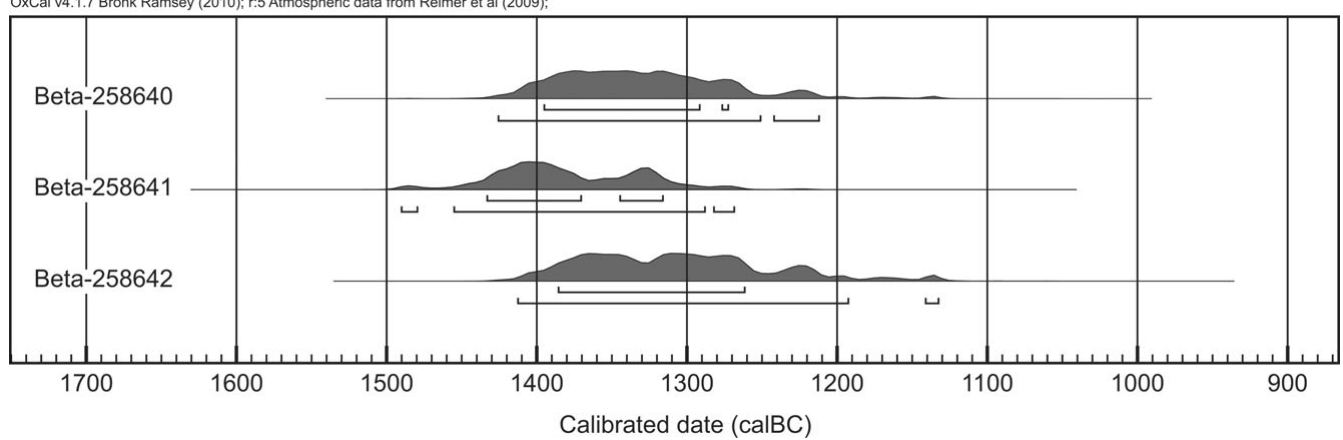

Figure 9. Probability distributions of radiocarbon dates from Corneşti (OxCal v.4.1.7).

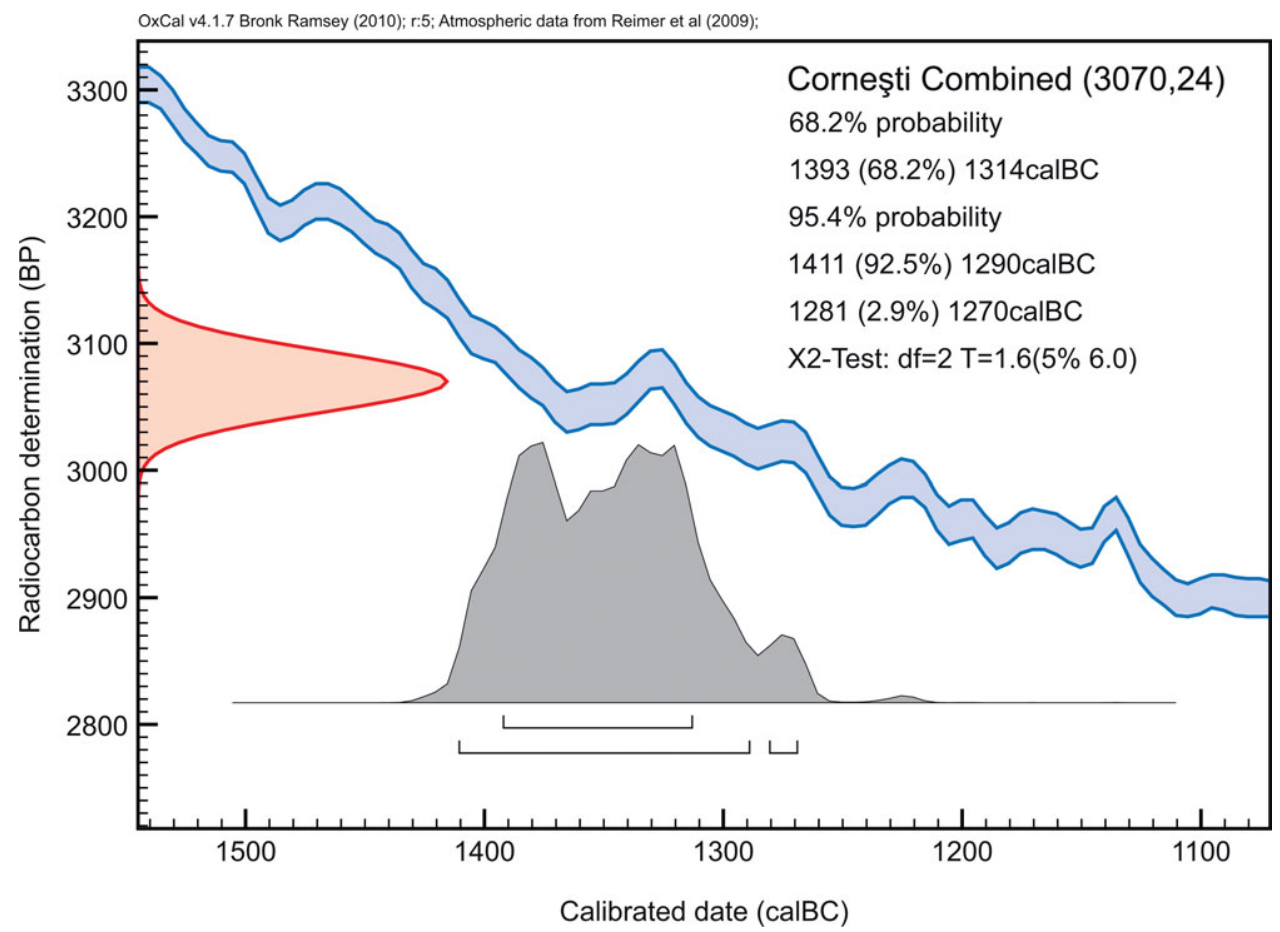

Figure 10. Combined probability distribution of the three radiocarbon dates (OxCal v.4.1.7). 


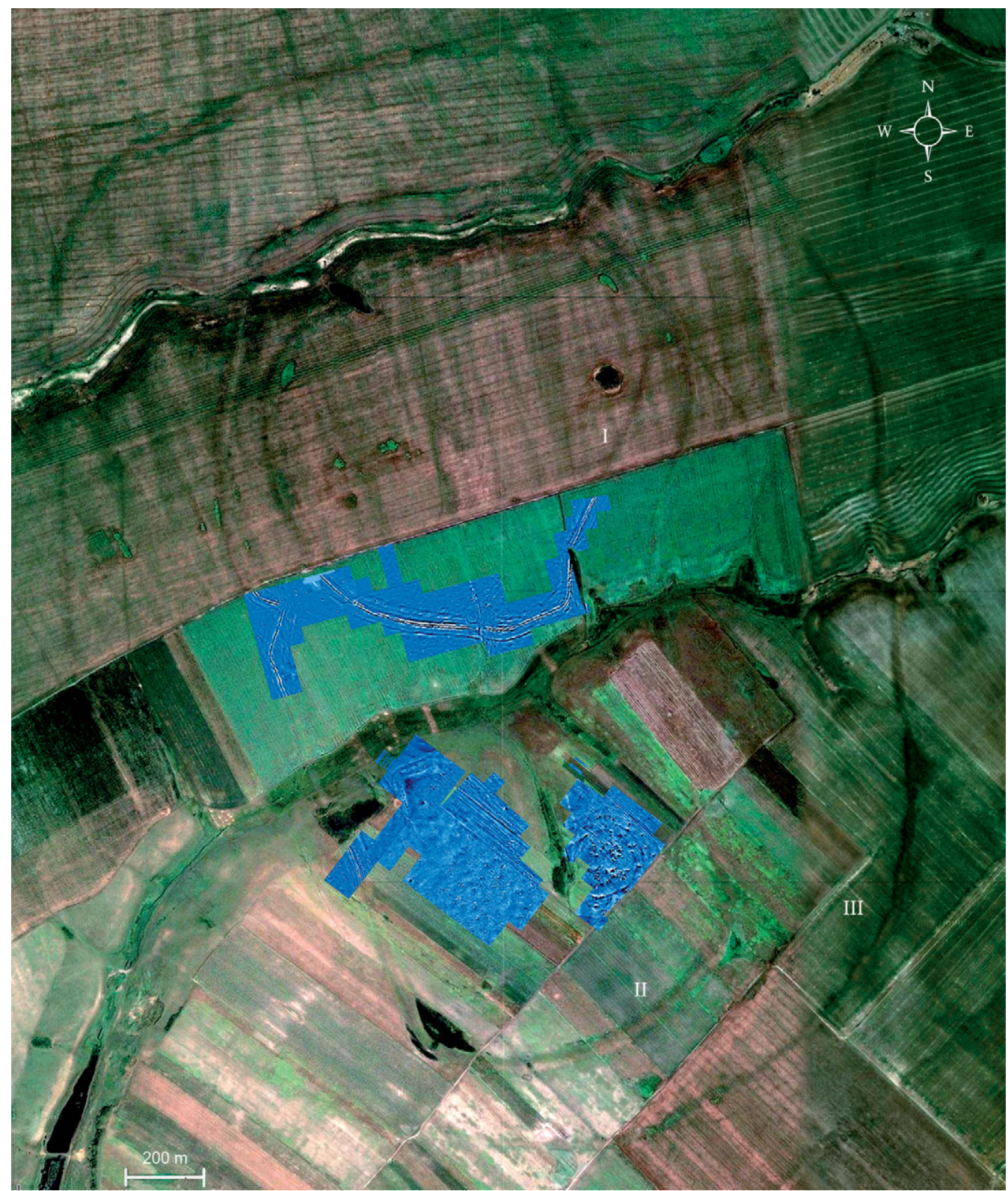

Figure 11. Survey magnetograms overlaid on the satellite image from Google Earth. Upper magnetogram (2008): southern part of Enclosure I and the west gate of Enclosure II; lower magnetograms (2009): interior of Enclosure II.

\section{The structure of Enclosure I}

Visible in the magnetometry of 2008 is the division of rampart I/A-B into two longitudinal parts, as seen in excavation. However, the high magnetic contrast caused by intense burning was, in this area, only produced on the outer side (Figure 12a). The crossbeams of the wooden compartments of rampart $\mathrm{I} / \mathrm{B}(5 \times 3 \mathrm{~m})$ did not burn through the whole rampart at 


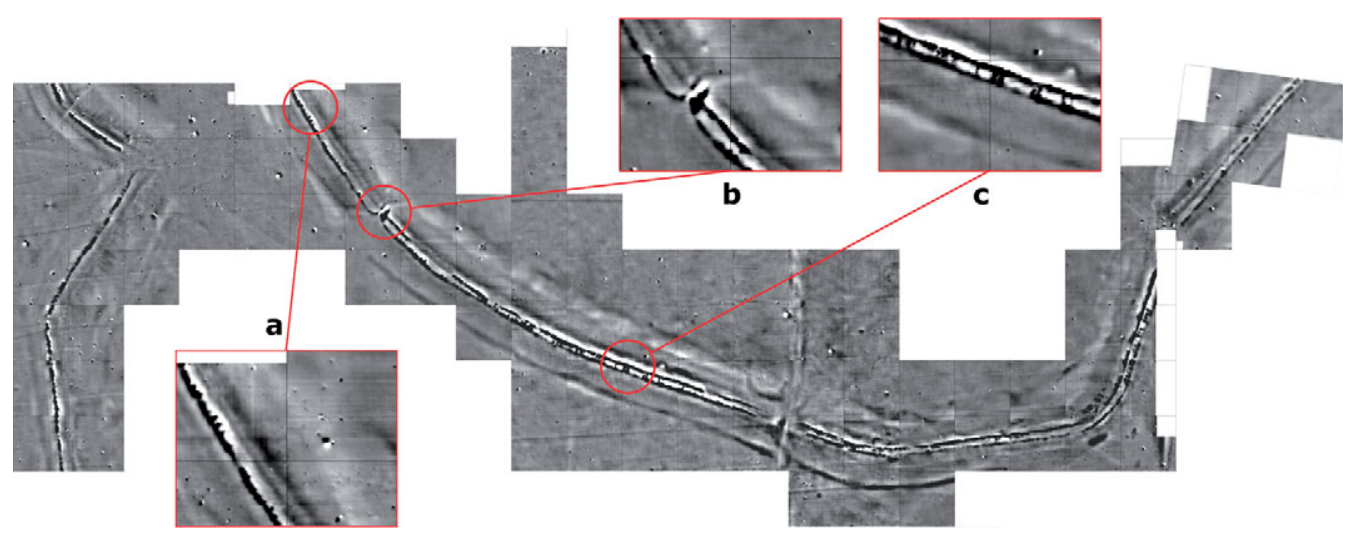

Figure 12a-c. Magnetogram (2008) of the southern part of enclosure I with three gates and the west gate of Enclosure II.

this point, but the $3 \mathrm{~m}$ divisions of the compartments are visible on the outer highly burnt façade of rampart I/B.

Three gates were detected in the southern part of Enclosure I. About $120 \mathrm{~m}$ south-east of Trench 2, a gateway must have existed with wooden flanks cutting rampart I/A-B (Figure $12 \mathrm{~b})$. This suggests that the remains of the older rampart I/A were used as a berm for the later rampart I/B. Around the south-west gate the fire spread to the inner wooden façade and caused catastrophic burning of the entire wooden construction of rampart I/B, including the crossbeams that go through the $5 \mathrm{~m}$ wide earth rampart, over the entire length of the surveyed area (nearly $1 \mathrm{~km}$ ) (Figure 12c). However, the interior of Enclosure I surveyed so far does not show any trace of settlement features (pits, fireplaces, houses etc.).

\section{Enclosure II}

The huge V-shaped west gate of Enclosure II was also covered by the survey of 2008 (Figure 13). The 1939 trench (B) is visible in the northern arm as a light line. The magnetogram shows that the wooden construction elements of rampart II are quite different from those in Enclosure I (rampart I/A-B), although rampart II can also be divided into two longitudinal packets (see red markings). The overall width of rampart II is about $10-11 \mathrm{~m}$, like rampart I/A-B, and had been burnt (as reported in the 1939 excavations, see above).

The survey in 2009 covered almost 22 ha in the southern half of Enclosure II (Figure 14). The campaign aimed to detect any settlement structures within Enclosure II. A number of remarkable results were achieved, notably the discovery of a $5 \mathrm{~m}$ wide earth rampart at the foot of the southern slope, some ten large pits aligned along the edge of the terrace, and a large part of the anticipated Late Bronze Age settlement (nos. 2, $3 \& 4$ in Figure 14). The magnetogram shows concentrations of pits, and large rectangular houses (about 20 or $25 \times 30 \mathrm{~m}$ ) possibly forming an urban scheme with lanes orientated along rampart II. It is difficult to identify clear outlines of houses in the magnetogram. However, it is possible that closer to the burnt rampart II some burnt houses exist, which may give a more precise 'city plan' once further survey is undertaken. There is also a remarkable number of circular structures with diameters of 8-12m, looking like flattened barrows (ring-ditches) or huts. 

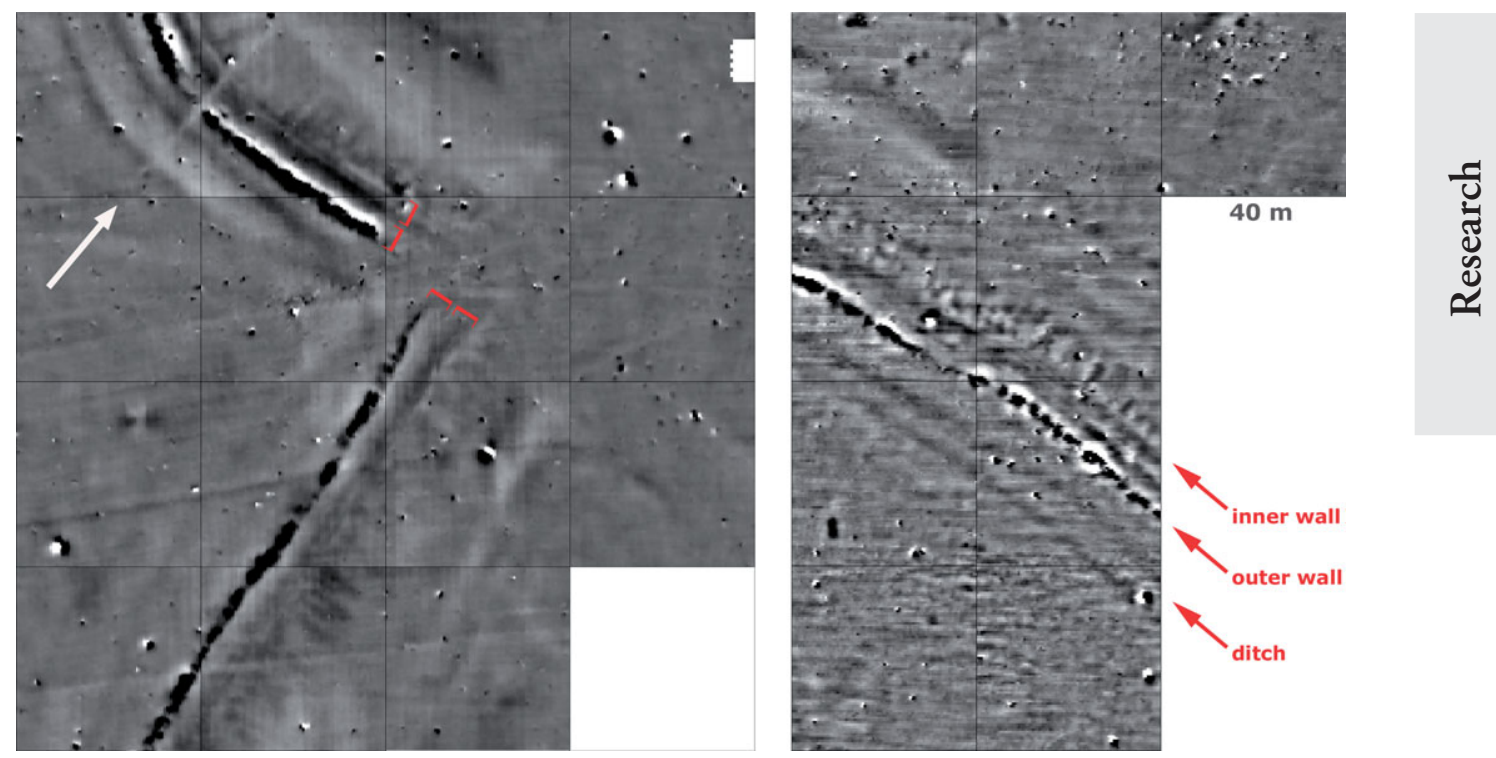

Figure 13. Left) magnetogram (2008) of the main west gate in Enclosure II with the trace of the 1939 excavation (white arrow), red lines indicate the two longitudinal packets of rampart II; right) magnetogram (2009) of part of enclosure II south of the valley.

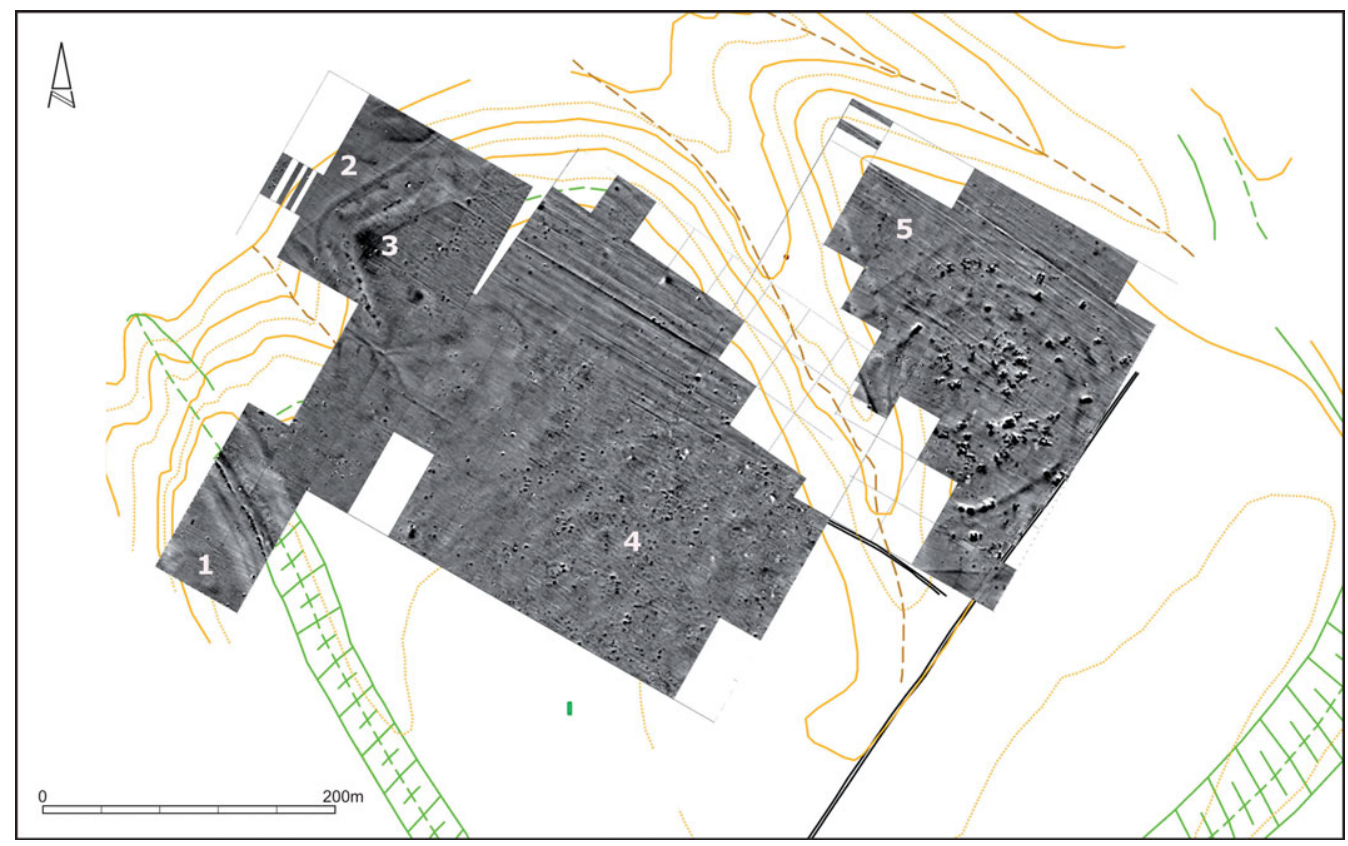

Figure 14. Magnetogram (2009) of the interior area of Enclosure II overlaid on the topographic map by D. Schäfler. It shows walls and ditches belonging to Enclosure II (1), an interior wall (2), a row of large pits (3), the Late Bronze Age settlement (4) and the Copper Age enclosure with burnt settlement remains inside (5). 
The eastern part of the area surveyed in 2009 is occupied by a large round enclosure about $300 \mathrm{~m}$ in diameter, consisting of four ditches (including at least one palisade) and highly burnt settlement features (no. 5 in Figure 14). The plan looks very similar to the Copper Age levels at Uivar (Schier \& Draşovean 2004: 151), where burnt houses of similar shape and radial orientation to the ditches were dated to the Tiszapolgár culture.

The enormous size of the quadruple enclosure at Corneşti, over $17 \mathrm{~km}^{2}$ in extent, represents a challenge, even for fast magnetometer systems. The instrument used at Corneşti was a Geometrics G-858G caesium-magnetometer in the so-called duo-sensor-configuration for two-track total field measurements, sensitivity $20 \mathrm{pT}$ at a cycle of $10 \mathrm{~Hz}$ (10 samples per second), dynamics $-20.0 /+20.0 \mathrm{nT}$ (white/black), raster $0.1 \times 0.5 \mathrm{~m}$ (interpolated to $0.25 \times 0.5 \mathrm{~m})($ Becker 1999). The caesium-magnetometer was used as it can detect even very faint magnetic anomalies caused by maghemite, biogenic magnetisation and from structures at greater depths (LeBorgne 1955; Fassbinder \& Stanjek 1993; Becker 1995; Tabbagh 2002). In 2008 and 2009 two parallel caesium sensors were used, although it is possible to use a four sensor system as has been shown elsewhere (Becker 2001; Neubauer et al. 2001). Fluxgate gradiometers are faster to use than caesium sensors (Erkul et al. 2005), but there are severe problems with induction effects (Dabas et al. 2007). Nevertheless an AMP system (Automatic Magnetic Profiling) could do a very rapid survey of the burnt parts of Enclosures I-IV, including all the gates. Burnt settlements could also be prospected in this way. Multisensor caesium or potassium magnetometry would need to be used for the non-burnt or biogenic magnetised structures, which are out of range for fluxgate gradiometry.

\section{Field-walking and topographic survey, 2009}

Based on the $40 \times 40 \mathrm{~m}$ grid of the magnetic prospection, a field-walking survey was carried out in 2009 using $20 \times 20 \mathrm{~m}$ squares in the southern part of Enclosure II. Almost 18 ha were covered. All objects that were not clearly of modern or post-medieval date were collected. Along with 9158 prehistoric sherds, we found mainly polished stone axes, worked flint and obsidian. Isolated bronze objects, some pieces of copper slag, quern fragments and spindle whorls were also collected. The distribution of the burnt daub shows a clear concentration in the area of the Neolithic/Eneolithic settlement. Quern fragments on the other hand occur more in the western half (Figure 15).

Of a total of 439 quadrants walked, 228 (51.9 per cent) contained sherds. Bronze Age sherds, which dominate the assemblage, were found on 185 (81.1 per cent) of the 228 quadrants. Sherds dating to the Neolithic and Iron Age are much less common. A spatial distribution of the ceramics shows that the Bronze Age sherds are fairly evenly spread over all quadrants. The Neolithic sherds, however, concentrate in the area of the Neolithic settlement. Especially noteworthy is the fact that the sherds show continuity from the Early Neolithic (Starčevo) to the Late Iron Age. The Iron Age sherds have a similar distribution to the Bronze Age sherds, but are a lot less frequent (Figure 16).

Analysis of the Bronze Age sherds shows that Early Bronze Age (Makó) finds are uncommon. The sherds become more frequent towards the Middle Bronze Age (Vatina). It is only in the Late Bronze Age (Cruceni-Belegiş) that sherds are found in all areas in relatively high numbers. Taking into account the radiocarbon dates and the results from 
Alexandru Szentmiklosi et al.

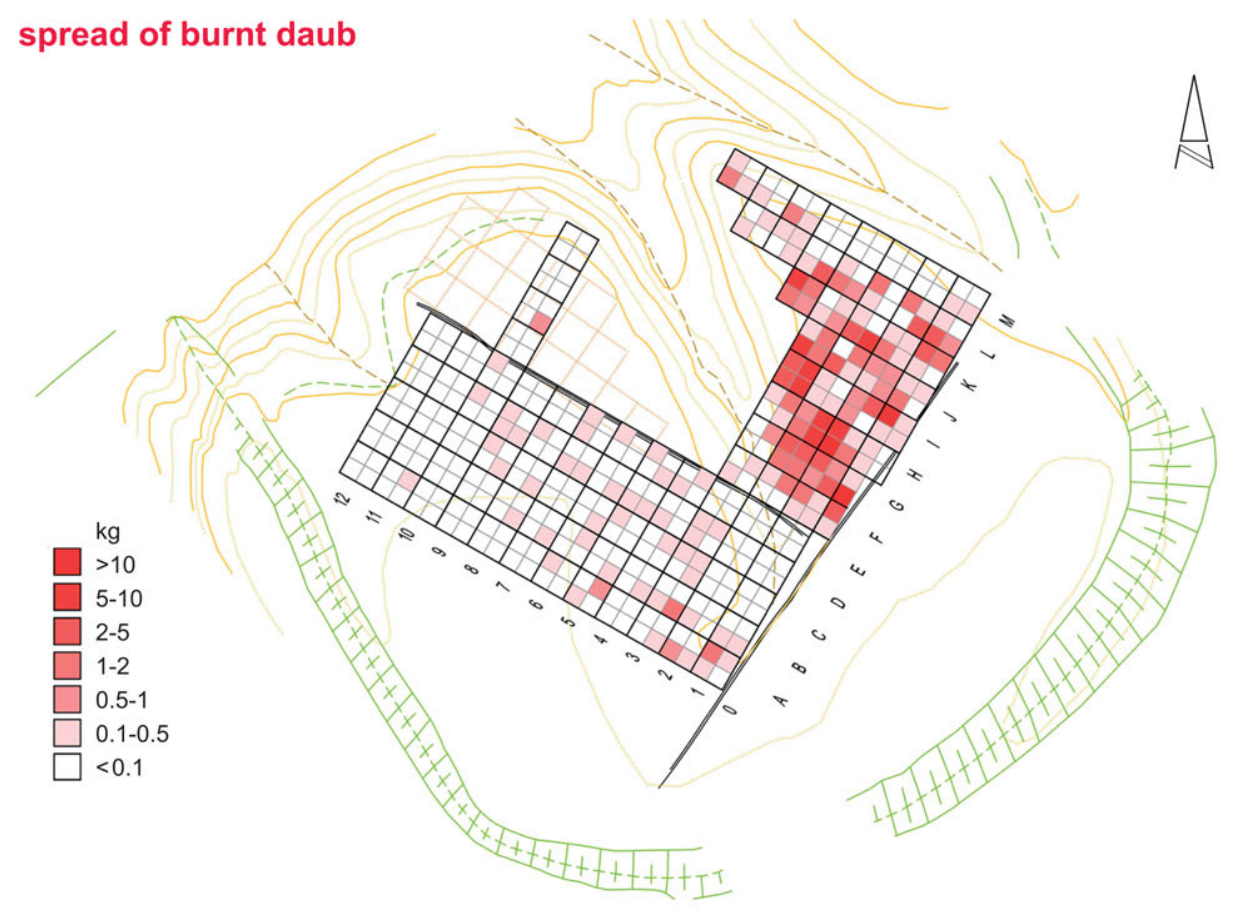

ปี

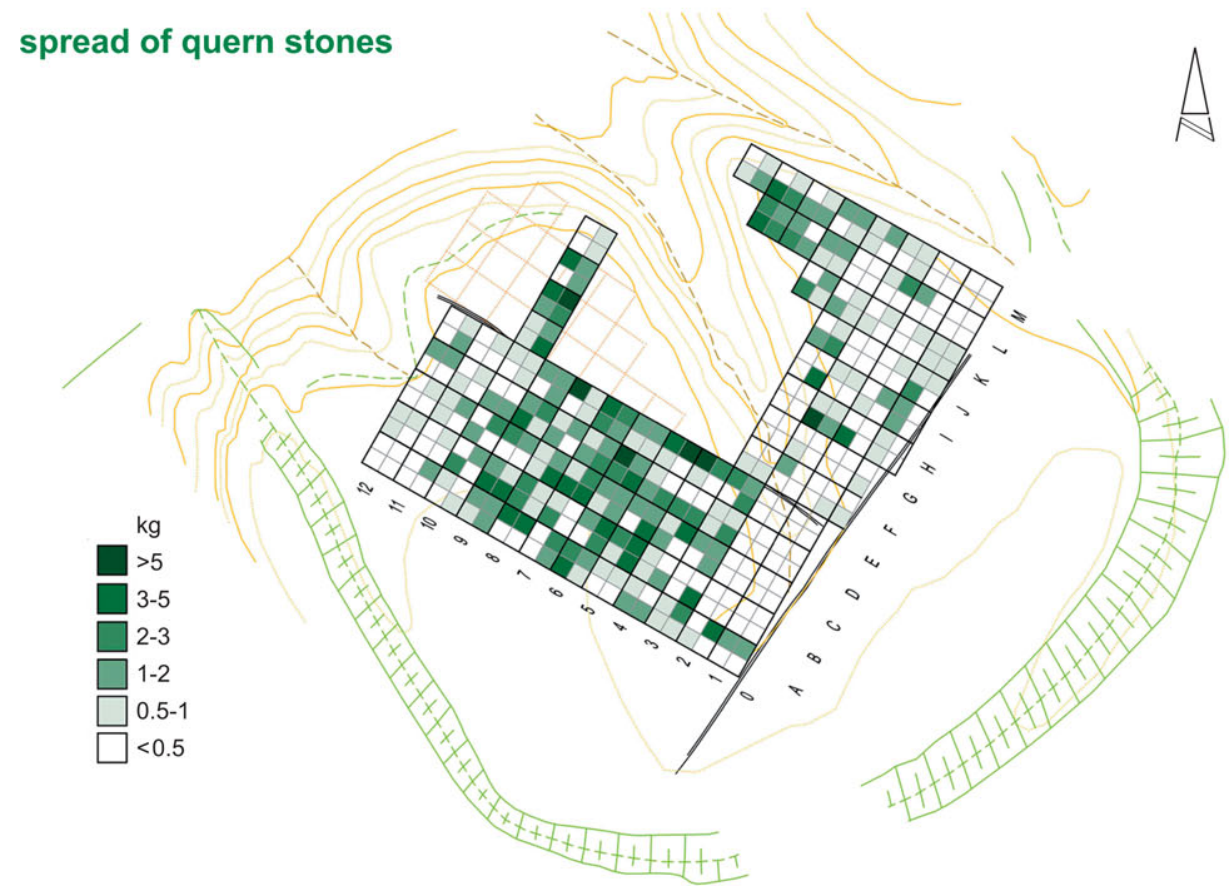

Figure 15. Areas field-walked in 2008 showing concentrations of burnt daub and querns. 


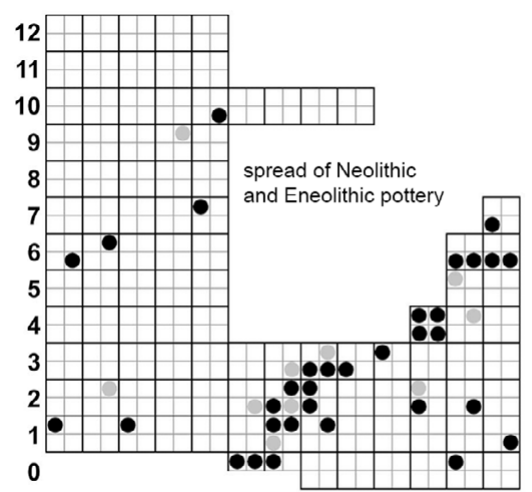

A B C D D E F G H I J K L

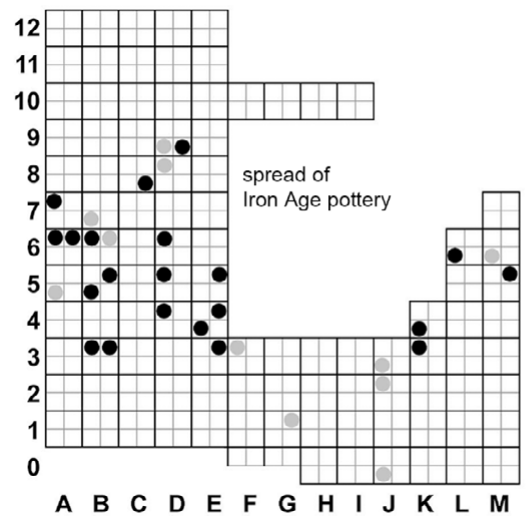

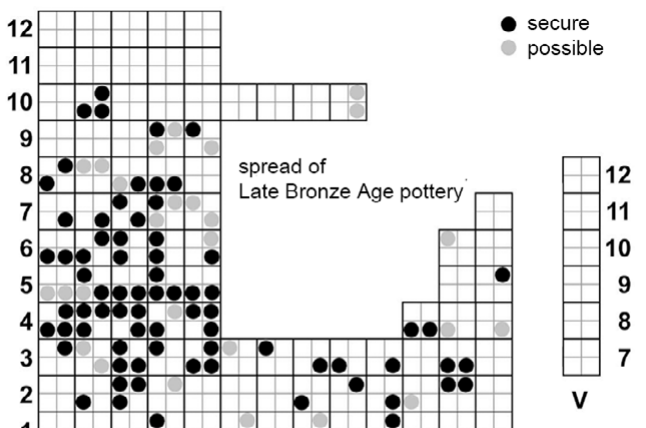

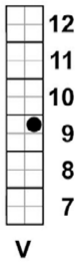

Figure 16. Sherds found in field-walking, by period.

field-walking, the evidence strongly suggests that the main settlement phase belongs to the Late Bronze Age.

The topography of large parts of the interior of Enclosure II were surveyed in 2009, using a Leica differential GPS set. In total over 60 ha were covered, resulting in a first topographic map of the southern part of Enclosure II. Since the magnetic and field-walking surveys were carried out in the same area, the results from each method can be overlaid (Figure 14).

\section{Discussion}

Corneşti-Iarcuri is a large and complex site, and work to date has provided a preliminary account of when and how it was constructed, how it developed and what lay inside it. The magnetic survey shows that we appear to be dealing with a defended site of urban character, while the radiocarbon and field-walking results indicate a Bronze Age date, confirming the assumption of Medeleţ (1993: 137) that it can be dated to the period between Bronze $C$ and Hallstatt A1. What is still not well understood is how such an enormous construction project could have been undertaken, either on this particular site or on others of the same date bearing in mind that so far the size of Corneşti-Iarcuri is unparalleled at this period either 
locally (the Romanian Banat), within the wider area (the Hungarian Plain and Transylvania), or internationally.

Corneşti gives every appearance of being a fortified site, but not, of course, a conventional one - its size alone rules that out. To make progress with our understanding of its possible defensive role we need to look at its local and regional context. At the moment little is known about the development of fortified sites in the Banat, though further south in the Vojvodina some analyses have been conducted on the Titel plateau (Falkenstein 1998). A site with many similarities to Corneşti-Iarcuri in terms of topographic situation and structure is Sântana near Arad (known in the older Hungarian literature as Szentanna), about $45 \mathrm{~km}$ away, and recently under excavation by a team from Cluj under the direction of Dr Florin Gogâltan. Earlier excavations on the site found a rampart sequence not dissimilar to that at Iarcuri with pottery from Eneolithic to Hallstatt B; the largest part fell in the periods Bronze D to Hallstatt A1, the pottery being mainly of Gava style (Rusu et al. 1999). This is close in time to what is present at Iarcuri, and Rusu et al. considered Iarcuri the closest analogy to Sântana even though Sântana, at 'only' $1 \mathrm{~km}$ in diameter, is considerably smaller. As excavations progress at both sites, it will become possible to specify these links more closely.

The effort necessary for the construction of two such large sites alone would be evidence for a social structure on a scale so far unheard of in Bronze Age Europe. In this connection, an enclosure at Variasu, Jud. Arad (40km from Corneşti) appears to be comparable in size to Sântana, noted recently on satellite images by Dr Ioana Oltean, University of Exeter. So far the date of the site is unknown. Dr Oltean will shortly begin aerial survey in this part of the Banat, with a view to setting these sites in context; this will be the most cost-efficient method of surveying the environs of Corneşti.

Looking further afield, Corneşti is relevant to the development of fortifications more generally in Bronze Age Europe. Within the Carpathian Basin, the extent to which tell sites were fortified has been a matter of considerable debate (e.g. Gogâltan 2008). The move towards defensive installations during the course of the Bronze Age is of considerable interest, with signs of a start in the Early Bronze Age, as seen in Otomani culture sites like Barca and Spišský Štvrtok in Slovakia (Vladár 1982), Otomani, Sălacea and other sites in western Romania (Bader 1982) as well as the castellieri in Istria such as Monkodonja (Teržan et al. 1999; Krause 2008: 79-82). A continuation into the Middle Bronze Age can be discerned, for instance in Hungary, where the Vatya culture saw the creation of many fortified settlements along the Danube (Kovács 1982). In northern Hungary and Slovakia too, sites of both the Middle Bronze Age Piliny and the succeeding Kyjatice cultures saw a number of fortifications erected and used (Furmánek et al. 1982; Kemenczei 1982). A marked increase in defended settlements can be noticed during the Urnfield culture in many parts of Europe (Harding 2000: 296). This 'stronghold horizon' probably begins in Hallstatt A2 (Rind 1999: 13) and stops in Hallstatt B3 (Jockenhövel 1990: 219). A similar situation may be discerned in Slovakia (Furmánek et al. 1982) and Transylvania (Soroceanu 1982).

So far the research into defended settlements has mainly concentrated on defended hilltop enclosures. As Iarcuri is situated on an expansive rolling plain, we are probably dealing with a rather different type of defended settlement. In the case of this extraordinary site, it is above all the position, size and structure of the site that give it its unique character. Iarcuri 
has little in common with the small settlements or villages that normally characterise sites of the Middle Bronze Age, or even the Late Bronze Age. A purely agrarian socio-economic framework for the society that built Iarcuri seems unlikely; the social and economic structures present must have included a range of craft specialisms and personal identities, probably including leadership and warriorhood. On the other hand, the site cannot have been purely urban in character across its full extent; the population would have been enormous. Our future programme of magnetometer survey will enable us to indicate where occupation was intensive and where it was slight or absent. In this way we will be able to suggest how defence might have been incorporated into the scheme of things, and how the site relates to 'normal' settlement in the area.

Such extensive ramparts would have been impossible to defend, which is why a purely defensive function for Corneşti-Iarcuri can be ruled out. The numerous gates so far known from Enclosures I and II also speak against the idea of defence as the main motive for the site's existence. Our thoughts therefore turn to social — or even ideological - explanations, involving prestige, power and display (e.g. Bowden \& McOmish 1989). We can deduce from the depth and width of ditch AU3 that rampart I/A must have had a height and depth of about $5 \mathrm{~m}$. A similar size can be assumed for phase I/B. If we presume for now that the ramparts of all four enclosures had similar dimensions, a total volume of $824000 \mathrm{~m}^{3}$ (at least 824000 tonnes of soil) would be implied. In addition to moving such large amounts of soil, the labour for acquiring the raw material and building the wooden constructions need to be taken into account, as well as general logistics like food procurement. The population of Iarcuri would not, in all probability, have been able to build such a site on its own. We are therefore talking about large numbers of people, from a sizeable area around Corneşti, who would have taken part in the site's construction. This brings with it the need to consider motivation, not to speak of logistics.

The three radiocarbon dates, along with the suggested pottery dating in the Late Bronze Age, indicate construction and use of the rampart of Enclosure I in the centuries around 3000 BP. Unfortunately the calibration curve is relatively flat at this period, which means that there is a sizeable potential spread of calendar dates, from 1400 to $1000 \mathrm{cal} \mathrm{BC}$ or even wider. The earlier part of this period might relate to the change to the Urnfield period and the spread of the cremation rite, while by the later part iron was starting to be used, and the Urnfield cultures were well developed. In this context we need to consider why the site came to an end, apparently after a relatively short occupation, and what this tells us about social and economic conditions in Central Europe at this time.

It is noticeable how many archaeological phenomena have produced radiocarbon dates at just this period. This was, for instance, the time when the dates for the great tumuli of the Suciu de Sus culture at Lăpuş in the Maramureş fall (Metzner-Nebelsick et al. 2010; C. Metzner-Nebelsick pers. comm.), and many other phenomena across Europe have been radiocarbon dated close to $3000 \mathrm{BP}$. Wolfgang Kimmig suggested many years ago that the start of the Urnfield period could be connected with far-reaching movements of people across the whole of Southern and Central Europe (Kimmig 1964), a theory that has never been refuted and continues to be attractive in many ways. Although it would be too simplistic to see a straight correlation between the new burial rite of cremation, and the rise of major fortifications, there are certainly attractive possibilities to explore in this general field. What 
seems certain is that major changes in economy and society were under way in Europe in the centuries after $1400 \mathrm{BC}$, and the construction of the Iarcuri enclosures is part of that development.

\section{Acknowledgements}

We express our thanks to J. Kalis, C. Metzner-Nebelsick, F. Gogâltan and I. Oltean for providing information used in this article, and to P. Raczky for helpful comments as referee for the article. Funding for the project has been provided by the Fritz-Thyssen-Stiftung, Köln, the County Council of Timiş and the Muzeul Banatului Timişoara, to whom we are most grateful.

\section{References}

BADER, T. 1982. Die befestigte bronzezeitlichen Siedlungen in Nordwestrumänien, in B. Chropovský \& J. Herrmann (ed.) Beiträge zum bronzezeitlichen Burgenbau in Mitteleuropa: 47-70. Berlin: Zentralinstitut für Alte Geschichte und Archäologie.

Becker, H. 1995. From Nanotesla to Picotesla - a new window for magnetic prospecting in archaeology. Archaeological Prospection 2: 217-28.

- 1999. Duo-and quadro-sensor configuration for high-speed/high-resolution magnetic prospecting with caesium magnetometry. Arbeitsheft Bayerisches Landesamt für Denkmalpflege 108: 100-105.

- 2001. Prospecting in Ostia Antica (Italy) and the discovery of the Basilica of Constantinus I. Monuments and Sites 6: 59-63.

Bowden, M. \& D. MCOMish 1989. Little boxes: more about hillforts. Scottish Archaeological Review 6: 12-16.

Dabas, M., X. Cassassolles, M. Chemin, L. Conte, A. Favard, J.M. Valet \& F.X. Simon. 2007. Integration of ARP and AMP for rescue archaeology: example of a 50 ha project. Studijné Zvesti 41: 129-31.

Erkul, E., C. Klein, W. Rabbel \& H. Stưmpel. 2005. Multisensor geophysical prospection of the archaeological site of Metaponte (Gulf of Tarent, Italy), in M. Posselt, B. Zickgraf \& C. Dobiat (ed.) Geophysik und Ausgrabung: Einsatz und Auswertung zerstörungsfreier Prospektion in der Archäologie (Internationale Archäologie 6): 53-7. Rahden: Marie Leidorf.

Fassbinder, J.W.E. \& H. Stanjek. 1993. Occurrence of bacterial magnetite in soils from archaeological sites. Archaeologia Polona 31: 117-28.

FalKensteIn, F. 1998. Die Siedlungsgeschichte des Titeler Plateaus (Feudvar: Ausgrabungen und Forschungen in einer Mikroregion am Zusammenfluß von Donau und Theißs. Volume 2) (Prähistorische Archäologie in Südosteuropa 14). Kiel: Oetker/Voges.
FurmáneK, V., L. VELIAČIK \& P. ROMSAUER. 1982. Jungbronzezeitliche befestigte Siedlungen in der Slowakei, in B. Chropovský \& J. Herrmann (ed.) Beiträge zum bronzezeitlichen Burgenbau in Mitteleuropa: 159-75. Berlin: Zentralinstitut für Alte Geschichte und Archäologie.

GogÂltan, F. 2008. Fortified Bronze Age tell settlements in the Carpathian Basin: a general overview, in J. Czebreszuk, S. Kadrow \& J. Müller (ed.) Defensive structures from Central Europe to the Aegean in the 3 rd and 2nd millennia BC (Studien zur Archäologie in Ostmitteleuropa 5): 39-56. Poznań: Wydawnictwo Poznańskie; Bonn: Habelt.

Harding, A. 2000. European societies in the Bronze Age. Cambridge: Cambridge University Press.

Heeb, B.S., A. Szentmiklosi \& J.M. Wiecken. 2008. $\mathrm{Zu}$ den Wallringen von Corneşti-Iarcuri, Jud. Timiş, Rumänien — Forschungsgeschichte und neueste Untersuchungen. Praehistorische Zeitschrift 83: 179-88.

JOCKENHÖVEL, A. 1990. Bronzezeitlicher Burgenbau in Mitteleuropa. Untersuchungen zur Struktur frühmetallzeitlicher Gesellschaften, in Orientalisch-ägäische Einflüsse in der europäischen Bronzezeit: Ergebnisse eines Kolloquiums (RGZM Monograph 15): 209-228. Bonn: Habelt.

KEMENCZEI, T. 1982. Der spätbronzezeitliche Burgenbau in Nordungarn, in B. Chropovský \& J. Herrmann (ed.) Beiträge zum bronzezeitlichen Burgenbau in Mitteleuropa: 273-8. Berlin: Zentralinstitut für Alte Geschichte und Archäologie.

KIMMIG, W. 1964. Seevölkerbewegung und Urnenfelderkultur. Ein archäologisch-historischer Versuch, in R. von Uslar \& K.J. Narr (ed.) Studien aus Alteuropa. Teil 1: 220-83. Köln: Böhlau.

KovÁCs, T. 1982. Befestigungsanlagen um die Mitte des 2. Jahrtausends v. u. Z. in Mittelungarn, in B. Chropovský \& J. Herrmann (ed.) Beiträge zum bronzezeitlichen Burgenbau in Mitteleuropa: 279-92. Berlin: Zentralinstitut für Alte Geschichte und Archäologie. 
Krause, R. 2008. Bronze Age hillforts in the Alps, in J. Czebreszuk, S. Kadrow \& J. Müller (ed.) Defensive structures from Central Europe to the Aegean in the $3 r d$ and 2 nd millennia BC (Studien zur Archäologie in Ostmitteleuropa 5): 65-84. Poznań: Wydawnictwo Poznańskie; Bonn: Habelt.

LEBORGNe, E. 1955. Susceptibilité magnétique anormale du sol superficial. Annales Geophysicae 11: 399-419.

MEDELEŢ, F. 1993. În legătură cu fortificaţia de pămînt de la Corneşti (comuna Orţişoara, judeţul Timiş). Analele Banatului S.N. Arheologie-Istorie 2: 119-50.

Metzner-Nebelsick, C., C. Kacsó \& L.D. NeBELSICK. 2010. A Bronze Age ritual structure on the edge of the Carpathian Basin, in L. Marta (ed.) Das Ende des 2. Jahrtausends v. Chr. auf der Theiß-Ebene und Siebenbürgen. Internationales Symposium für Archäologie in Satu Mare 18-19 julie 2008: 219-33. Satu Mare: Editura Muzeului Satmarean.

Micle, D., L. Măruia \& L. Dorogostaisky. 2006. The earth works from Corneşti-'Iarcuri' (Orţişoara village, Timiş county) in the light of recent field research. Analele Banatului S.N. Arheologie-Istorie 16: 283-305.

MilleKer, B. 1899. Délmagyarország régiségleletei a honfoglalás elótti idókböll, II, Római, római korszaki barbár és népvándorláskori leletek. Temesvár (Timişoara): Csanád-egyházmegyei Könyvnyomda.

Neubauer, W., P. Melichar, R. Steiner \& A. Eder-Hinterleitner. 2001. High resolution multisensor caesiummagnetometer devices, in W. Doneus, A. Eder-Hinterleitner \& W. Neubauer (ed.) Archaeological Prospection: Fourth International Conference on Archaeological Prospection, Vienna, 19-23 September 2001: 156-8. Vienna: Prehistoric Commission of the Austrian Academy of Sciences.

PECH, J. 1877. A zsadányi avar telepek Temesvármégyében. Történelmi és Régészeti Értesitö" 3: 49-59.

Rada, M., N. Cochină \& D. Manea. 1989. Studiu aerofotogrammetric al fortificaţilor de la Corneşti, Jud Timiş. Studii şi Cercetari de Istorie Veche, Archeologie 40: 377-80.
RIND, M.M. 1999. Der Frauenberg oberhalb Kloster Weltenburg. Volume I (Regensburger Beiträge zur Prähistorischen Archäologie 6). Regensburg: Universitätsverlag Regensburg.

Rusu, M., E. Dörner \& I. Ordentlich. 1999. Die Erdburg von Sântana-Arad in dem zeitgleichen archäologischen Kontext, in N. Boroffka \& T. Soroceanu (ed.) Transsilvanica: archäologische Untersuchungen zur älteren Geschichte des südöstlichen Mitteleuropa. Gedenkschrift für Kurt Horedt (Internationale Archäologie 7): 143-65. Rahden: Marie Leidorf [German version of Romanian original in Ziridava 19-20 (1996): 15-26].

SCHIER, W. \& F. Draşovean. 2004. Vorbericht über die rumänisch-deutschen Prospektionen und Ausgrabungen in der befestigten Tellsiedlung von Uivar, jud. Timiş, Rumänien (1998-2002). Praehistorische Zeitschrift 79: 145-230.

SzENTMIKLOSI, A. 2009. Settlements of the Cruceni-Belegiš culture in the Romanian Banat. Unpublished Dissertation, University of Alba Iulia '1 Decembrie 1918'.

SorocEANU, T. 1982. Hortfunde und befestigte Anlage in Transsilvanien, in B. Chropovský \& J. Herrmann (ed.) Beiträge zum bronzezeitlichen Burgenbau in Mitteleuropa: 363-76. Berlin: Zentralinstitut für Alte Geschichte und Archäologie.

TABBAGH, J. 2002. Total field magnetic prospection: are vertical gradiometer measurements preferable to single sensor survey? Archaeological Prospection 10: 75-81.

TerŽAn, B., K. Mihovilić \& B. Hänsel. 1999. Eine protourbane Siedlung der älteren Bronzezeit im istrischen Karst. Praehistorische Zeitschrift 74: 154-93.

VLADÁR, J. 1982. Die frühbronzezeitliche Entwicklung der Slowakei und das Aufkommen des befestigten Siedlungen, in B. Chropovský \& J. Herrmann (ed.) Beiträge zum bronzezeitlichen Burgenbau in Mitteleuropa: 437-53. Berlin: Zentralinstitut für Alte Geschichte und Archäologie. 